\section{Nuclear war - counting the cost}

SIR - Recent papers on the consequences of nuclear war ${ }^{1,2}$ have not attempted to relate their findings to historical events. There are at least three events that appear relevant. The ozone depletion from the 1908 Tunguska meteor was found by Turco et al. ${ }^{3}$ to be comparable with that expected from a 5,000-10,000 megaton nuclear war. Stothers' study ${ }^{4}$ of the volcanic dust cloud of AD536 found its optical depth to have been between 2.2 and 2.5 and its duration to have been approximately one year, comparable with nuclear war models. The intense incendiary attacks on Japanese cities during the last months of the Second World War offer a test of the injection and retention of large quantities of urban smoke in the atmosphere. All three of these events could conceivably be used to normalize the models to actual events but the smoke study requires the use of recent meteorological and astronomical data.

The measured area of the total destruction by fire from the well documented USAAF attacks on Japan between 9 March and 18 August 1945 was 178 square miles $\left(464 \mathrm{~km}^{2}\right)^{5}$ or 1.8 per cent of the burned area of the smallest attack (100 megaton cities only) necessary to produce a nuclear winter ${ }^{1}$.

Eddy et al. ${ }^{6}$ noted that 0.1 to 0.2 per cent changes in solar output, as measured by spacecraft, can be related to the fraction of the solar disk covered by sunspots. By using spectral analysis techniques appropriate to low signal to noise ratio signals, Currie ${ }^{7}$ discovered that between 1870 and 1977 there existed an inland temperature variation of $0.18^{\circ} \mathrm{C}$ with a frequency matching that of the solar cycle. Eddy demonstrated ${ }^{6}$ that such a variation can be driven by sunspot blockage of the solar disk. Since the nuclear winter implies a near total blockage of sunlight, the much smaller attacks on Japanese cities can be expected to produce an effect comparable to the changing sunspot areas but to my knowledge there have been no attempts to investigate the historical record for such an effect.

WILLIAM H. BOWN

757 Rose Lane,

Los Altos,

California 94022, USA

1. Turco, R.P., Toon, O.B., Ackerman, T., Pollack, J.B. \& Sagan, C. Science 222, 1283-1300 (1983).

2. Covey, C., Schneider, S.H. \& Thompson, S.L. Nature 308 21-25 (1984).

Turco, R.P. et al. Science 214, 19-23 (1981).

3. Turco, R.P. et al. Science 214, 19-23 (1981).

4. Stothers, R.B. Nature 306, 344-34s (1984). Mac Isaac, D. The Uniled States Strategic Bombing Survey, Vol X, 1976).

6. Eddy, J.A., Gilliland, R.L. \& Hoyt, D.V. Nature 300 , 689-693 (1982).

7. Currie, R.G. J. atmos. Sci. 38, 808-818 (1981).

SIR - The known behaviour of smoke in the aftermath of large fires raises questions about the climatic conclusions of Turco et $a l .{ }^{1}$ and Covey et $a l{ }^{2}$. The recent work of Stothers ${ }^{3}$ suggests that a 90 per cent reduction of solar insolation (even over several months) will not cause freezing surface temperatures. Even regionally persistent smoke (one month duration - from nearby forest fires) does not cause surface freezing $^{4}$, contradicting the claim of Covey et al. that smoke clouds persisting over a region for a few days would do so.

Covey et al. also note that a major uncertainty in "nuclear winter" is the extent of prompt smoke removal. This effect is demonstrated by the "black rain" following some firestorms during the Second World War ${ }^{5-7}$. Large fires themselves can cause thunderstorms ${ }^{8}$.

A major factor in the atmospheric residence time of smoke in the atmosphere is the altitude to which it rises. Turco et al. allow for firestorm smoke to enter the stratosphere, but none of the Second World War firestorms lofted smoke to such heights ${ }^{5-9}$, nor did much larger (approximately $1,000 \mathrm{~km}^{2}$ ) natural firestorms ${ }^{10}$.

The great spread of forest fire smoke (several thousand $\mathrm{km}$ distance) discussed by Crutzen and Birks ${ }^{11}$ may not be typical. Special upper-atmospheric circulation patterns are credited with both the great distance covered by the 1918 Minnesota fire smoke pall ${ }^{12}$ and the transoceanic spread of smoke from the 1950 Alberta fires ${ }^{13,14}$. Smoke from nuclear fires may not easily spread far beyond its origins.

Turco et al. consider 100 million tons of smoke sufficient for major hemisphericscale climatic perturbations. Such a total (or significant fraction thereof) could have been reached during historic fires, evidently without climatic perturbation. Areas of over $25,000 \mathrm{~km}^{2}$ have burned simultaneously ${ }^{15}$. Masses of $4.2 \mathrm{~g} \mathrm{~cm}^{-2}$ are possible for mature forests ${ }^{16,17}$. Assuming 3 per cent smoke emission and $2 / 3$ fuel consumption (possible for high-intensity fires ${ }^{19}$ ), more than 20 million tons of smoke particles can be generated in only one such natural fire.

\section{Northeastern Illinois University}

JAN PeCZKIS

\section{Chicago 60625, USA}

1. Turco, R.P., Toon, O.B., Ackerman, T., Pollack, J.B. \& Sagan, C. Science 222, 1283-1300 (1983).

2. Covey, C., Schneider, S.H. \& Thompson, S.L. Nature 308 21-25 (1984).

3. Stothers, R.B. Nature 307, 344-5 (1984)

4. Boerker, R.H.D. Behold Our Green Mansions, 149 (University of North Caroline Press, 1945).

5. Caidin, M. The Night Hamburg Died, 94 (Ballantine, New York, 1960).

6. U.S. Strategic Bombing Survey Vol. X, 96-97 (1976).

7. Hiroshima and Nagasaki, 88-94 (Basic Books, New York 1981)

8. Vogl, R.J. in Fire and Ecosystems (eds Kozlowski, T.T. \& Ahlgren, C.E.) 153 (Academic, New York 1974).

9. Irving, D. The Destruction of Dresden, 173 (Ballantine, New York, 1963).

10. Pyne, S.J. Fire in America, 300 (Princeton University Press, 1982).

11. Crutzen, P.J. \& Birks, J.W. Ambio 11, 115-125 (1982).

12. Lyman, H. Mon. Weath. Rev., 509 (1918).

13. Bull, G.A. Met Mag. 80, 3 (1951).

14. Smith, Mon. Weath. Rev., 193 (1950).

15. Pyne, S.J. Fire in America, 506 (Princeton University Press, 1982)

16. Edgell, M.C.R. Nature and Perception of the Bushfire Hazard in Southeastern Australia, 8 (Monash University, Melbourne, 1973).

17. Wright, H.A. \& Bailey, A.W. Fire Ecology, 274 (Wiley, New York, 1982)
18. McClement, F. The Flaming Forest, $46-47$ (McClelland \& Stewart, Toronto 1969).

19. Barrett, J.W. Regional Silviculture of the United States 2 nd edn, 351 (1980)

These two letters are a foretaste of a large amount of correspondence (on both sides) on this topic - Editor Nature.

\section{The origins of malignancy}

SIR - As an outsider, I would like to raise some questions about the distinctive features of malignant tissue.

One may suppose that the growth of normal tissue is regulated by the inhibition of cell division by some material produced by daughter cells. This mechanism suggests that cells produce substances which attach to receptor sites on the membrane of the cells involved, inhibiting cell growth and division; the inhibitors appear to be relatively tissue specific.

Accordingly, excessive growth in malignant tissue could be caused by a breakdown in this feedback mechanism. Although it is possible that malignant cells produce insufficient inhibitory substances to control their own growth, it seems more likely that the cells continue to produce these substances but are relatively unresponsive to them.

If the degree of specificity of the substances produced by malignant cells for the receptors of normal cells is sufficiently high, then the growth and division of normal tissue will be inhibited. As the malignant cells replicate in ever-increasing numbers, more and more growth inhibitory substances will be produced, overriding tissue specificities between different tissue types.

By extending this view of malignancy to its effect upon normal tissue, a number of clinical manifestations can be explained. First, benign tumours generally grow only by expansion and the surrounding compressed connective tissues tend to enclose the growth in a capsule. Malignant tumours, by contrast, grow also by infiltration and invasion. If malignant cells simply replicate at an enhanced rate, then expansion would occur along the lines of least resistance and physical restrictions would predominate. But if malignant cells also inhibit the growth and replication of the surrounding normal tissue, then invasion may be expected. Malignant cells would invade by inhibiting their competitors.

Second, malignant tissue has poorly developed blood vessels and bleeding occurs easily. Again this may be explained by the excessive concentration of growth inhibitory substances acting on normal tissue.

Third, advanced disseminated cancer is often accompanied by cachexia or generalized atrophy. When the malignancy is very extensive, then wasting of all normal tissues ensues.

Some cancers are typified by an extremely fast growth rate. Others which are equal- 